\title{
Job Satisfaction and Organisational Commitment: A Study of Library Personnel in Private Universities in Ogun State, Nigeria
}

\author{
Toyosi Daniel Samuel, Uloma Doris Onuoha, Adebowale Ifeoluwa Ojo \\ Babcock University, Ilishan Remo, Nigeria \\ Email: toyosidaniel@yahoo.com, ud onu@yahoo.com, adebowaleojo@ymail.com
}

Received 6 July 2014; revised 26 August 2014; accepted 28 September 2014

Copyright (C) 2014 by authors and OALib.

This work is licensed under the Creative Commons Attribution International License (CC BY). http://creativecommons.org/licenses/by/4.0/

(c) (i) Open Access

\section{Abstract}

This study investigated job satisfaction and organisational commitment among library staff in private universities in Ogun State, Nigeria. The survey research design was used for the study. Study population consisted of 162 library personnel in seven private university libraries. Sampling was enumerative as all members of the population were used for the study. A questionnaire titled "Job Satisfaction and Organisational Commitment (JSOC)" was used for data collection. Data collected were analysed using frequency and percentage counts. Library personnel were found to be generally satisfied with their jobs even though they faced some constraints. They were also found to be committed to their organisations, although the level of job satisfaction was found to be higher than organisational commitment. Based on the findings, recommendations were made.

\section{Keywords}

Job Satisfaction, Library Personnel, Organisational Commitment

Subject Areas: Information Science, Library, Intelligence and Philology

\section{Introduction}

The connection between man and work has always been of great interest to philosophers because the work place is not just where men and women spend most part of their waking hours; it is also a source of livelihood and prestige. Every organisation depends on human beings to carry out its functions. University libraries in particular, are highly dependent on the men and women employed to carry out various functions of a library. The selection, acquisition and processing of information resources are human functions carried out by library personnel [1]. Library personnel in carrying out their duties are expected to be committed to the values and goals of the library. Indeed, without commitment on the part of employees, organisations simply fold [2]. Organisational 
commitment can be a driving force behind a company's performance as committed employees are proud to have a sense of membership, believe in the goals and values of the organisation, and, therefore, display higher levels of performance and productivity [3]. While it is important that employees remain committed to their organisations, it is equally important for them to have a sense of fulfilment in what they do. Job satisfaction, therefore, has been investigated by several disciplines such as psychology and management science. Job satisfaction is an important concept that can affect labour market behaviour, influence productivity, work effort, employee absenteeism and staff turnover [4]. Considering the fact that private universities in Nigeria operate within limited funds being cut off from any form of federal government assistance, it is necessary to have dedicated personnel who are not just satisfied with their work but who are committed to the goals of the organisation. It is against this background that the present study investigates job satisfaction and organisational commitment among library personnel in private universities in Ogun State, Nigeria.

\section{Statement of the Problem}

The survival of every organisation is dependent on the personnel who carry out the day to day activities of the organisation. While organisations desire high level performance from their personnel, this may not always be the case as some employees may not be satisfied with their jobs or are not committed to the organisation. Where such is the case, the organisation would suffer consequences such as high rate of staff turnover, low productivity, and high rate of absenteeism. It is in the light of the above that the present study sought to assess job satisfaction and organisational commitment among library personnel in private universities in Ogun State.

\section{The specific objectives of the study were to:}

1) ascertain the level of job satisfaction among personnel in private university libraries in Ogun State;

2) ascertain the level of organisational commitment among personnel in private university libraries in Ogun State;

3) identify the constraints to job satisfaction among personnel in private university libraries in Ogun State;

4) identify the constraints to organisational commitment among personnel in private university libraries in Ogun State.

\section{Review of Related Literature}

\subsection{Concept of Job Satisfaction}

Job satisfaction is defined as a general attitude or reaction of employees in relation to their jobs and the job elements such as the working environment, working conditions, impartial rewards, and communication with colleagues [5]. It is a positive feeling about a job, emanating from an evaluation of its characteristics [6]. There are hierarchies of needs, which propel job satisfaction [7]. These needs range from basic or lower level needs to higher level needs, which are: physiology, safety, belongingness and esteem and self-actualization. The implication of Maslow's hierarchy of needs is that lower level needs would be taken care of before the consideration of higher level needs. Employees would thus derive maximum job satisfaction only when they have gotten to the pinnacle of the needs hierarchy. Job satisfaction is related to employees' opportunities for interaction with others on the job [8]. Individuals are likely to have high levels of job satisfaction if supervisors provide them with support and cooperation in completing their tasks [9].

In a study of job satisfaction, Moorhead and Griffen [10] found out that working conditions have moderate impact on employee's job satisfaction. In another study of public sector managers, Taylor and Vest [11] found out that pay affects job satisfaction. Luthans [12], however, affirms that employees derive satisfaction from interesting and challenging job that provides them with status.

A more recent study of librarians at Quebec by Sierpe [13] affirms that although librarians are generally satisfied with their jobs, they are however, dissatisfied with communication and operating procedures. A study by Togia et al. [14] which examined job satisfaction among Greek academic librarians, affirmed that librarians are generally satisfied with their jobs but dissatisfied with pay and promotions policies. Bonnie [15], studied over 600 academic librarians in the United States to determine whether faculty status and rank were related to job satisfaction, the result of the study reveals that the greatest sources of satisfaction is relationship with patrons, co-workers, assigned duties, and variety of work. Dissatisfaction comes up as a result of opportunities for promotion, recognition of accomplishments and salary. Similar research by Haque et al. [16] identifies causes of 
dissatisfaction among library personnel as poor public perception of librarians, constraints of facilities and space as well as skewed communication.

Fanimehin and Popoola [17] in a study of library personnel in the Federal Civil Service of Nigeria affirm that library personnel are mostly satisfied with the way co-workers relate with each other, the way their services are appreciated by others and the leadership competence of superior officers. The factors that least contributes to job satisfaction are found to be: take home pay, availability of equipment to facilitate duties and training for library personnel.

\subsection{Organisational Commitment}

Organisational commitment has to do with the employee's emotional attachment to, identification with, and involvement in the organisation. It is the promise and pledge of any responsibility in the future [18] characterized as employees' natural willingness to contribute to organisational goals. Meyer and Allen [19] identified three components of organisational commitment namely: affective commitment, continuance commitment and normative commitment. Affective commitment is the psychological attachment to organisation; continuance commitment refers to the cost associated with leaving the organisation while normative commitment is the perceived obligation to remain with the organisation. The success of an organisation and the pursuit of quality depend not only on how the organisation makes the most of human competencies, but also on how it stimulates commitment to an organisation. Greater commitment can result in enhanced feelings of belonging, security, efficacy, greater career advancement, increased compensation and increased intrinsic rewards for the individual. When employees are sure that they will grow and learn with their current employers, their level of commitment to stay with that particular organisation is higher [20].

Hart's [21] study using a South African Academic library in transition found out that workers are more satisfied with their work as affirmed by $61 \%$ of the respondents than they are committed to the library as only $51 \%$ claim to be proud to work at the library. The causes for low commitment include a sense of stagnation, frustration with inadequate resources, and anger at poor remuneration. Curry et al. [22] on the other hand, affirm that task ambiguity and promotional opportunities can enhance or diminish organisational commitment. Personal characteristics such as age, years of service and gender also affect organisational commitment as older employees and those with tenure or seniority are found to possess higher levels of organisational commitment [19] [23]. Benkhoff [24] opines that management style/supervisory relationship affects organisational commitment by noting that when individuals find the supervisory relationship to be fair in its practices, they tend to be more committed to the organisation.

\subsection{Methodology}

The survey research design was used for this study. Study population consisted of 162 library personnel in seven private university libraries in Ogun state, Nigeria. Sampling was enumerative as all members of the population were used for the study. A questionnaire titled "Job Satisfaction and Organisational Commitment (JSOC) was used for data collection. The questionnaire measured job satisfaction using statements adapted from Minnesota job satisfaction questionnaire as well as organisational commitment using statements adapted from Allen and Meyer [19].

\subsection{Presentation of Findings}

A total of 162 copies of the questionnaire were distributed out of which 114 were retrieved. Table 1 gives a breakdown of distribution.

Table 1 reveals that the highest response rate was gotten from Crawford University as affirmed by the $100 \%$ response rate followed by McPherson University which had a response rate of $85.7 \%$. The least response rate came from Covenant University with a response rate of 52.1\%. However, when summed together the response rate came to $70.3 \%$, which is considered adequate for a study of this nature.

Indications from Table 2 affirm that library personnel in private universities in Ogun State, Nigeria are generally satisfied with the work. This is revealed in the overall mean score of 2.51. The respondents also indicated that they are generally satisfied with their work with the mean score of 2.52. Relationship with supervisors, co-workers and office environment accounted for most part of the satisfaction while the least areas of satisfaction were found to be pay (salary) and opportunity for personal development. 
Table 1. Distribution of questionnaire.

\begin{tabular}{clccc}
\hline S/N & \multicolumn{1}{c}{ University } & Copies of questionnaire administered & No. returned & \% of response rate \\
\hline 1 & Babcock University & 29 & 21 & $72.4 \%$ \\
2 & Bells of University Of Technology & 20 & 14 & $70 \%$ \\
3 & Covenant University & 46 & 24 & $52.1 \%$ \\
4 & Crawford University & 15 & 15 & $100 \%$ \\
5 & Crescent University & 13 & 10 & $76.9 \%$ \\
6 & Mcpherson University & 7 & 6 & $85.7 \%$ \\
7 & Redeemer's University & 32 & 22 & $68.7 \%$ \\
& Total & $\mathbf{1 6 2}$ & $\mathbf{1 1 4}$ & $\mathbf{7 0 . 3 \%}$ \\
\hline
\end{tabular}

Table 2. Job satisfaction of library personnel.

\begin{tabular}{|c|c|c|c|c|c|c|c|}
\hline $\mathrm{S} / \mathbf{N}$ & On my present job, I am satisfied with... & Very satisfied & Satisfied & Fairly satisfied & Dissatisfied & Very dissatisfied & Mean \\
\hline 1 & the relationship with my supervisor & $35(30.7 \%)$ & $65(57.0 \%)$ & $11(9.6 \%)$ & $2(1.8 \%)$ & $1(0.90 \%)$ & 2.98 \\
\hline 2 & the physical environment of the library & $33(28.9 \%)$ & $61(53.1 \%)$ & $13(11.4 \%)$ & $4(3.5 \%)$ & $3(2.6 \%)$ & 2.86 \\
\hline 3 & $\begin{array}{l}\text { the cooperation I received from } \\
\text { my co-workers }\end{array}$ & $28(24.6 \%)$ & $64(56.1 \%)$ & $14(12.3 \%)$ & $7(6.1 \%)$ & $1(0.9 \%)$ & 2.80 \\
\hline 4 & $\begin{array}{l}\text { the interior design and ambiance } \\
\text { of my workplace }\end{array}$ & $30(26.3 \%)$ & $56(49.1 \%)$ & $15(13.2 \%)$ & $11(9.6 \%)$ & $2(1.8 \%)$ & 2.74 \\
\hline 5 & my office environment & $31(27.2 \%)$ & $56(49.1 \%)$ & $18(15.8 \%)$ & $6(5.3 \%)$ & $3(2.6 \%)$ & 2.69 \\
\hline 6 & the way my boss handles his/her workers & $28(24.6 \%)$ & $53(46.5 \%)$ & $13(11.4 \%)$ & $11(9.6 \%)$ & $9(7.9 \%)$ & 2.65 \\
\hline 7 & the praise I get for doing a good job & $22(19.3 \%)$ & $55(48.2 \%)$ & $27(23.7 \%)$ & $4(3.5 \%)$ & $6(5.3 \%)$ & 2.34 \\
\hline 8 & $\begin{array}{l}\text { the policies attached to promotion in } \\
\text { my work place }\end{array}$ & $16(14.0 \%)$ & $48(42.1 \%)$ & $24(21.1 \%)$ & $19(16.7 \%)$ & $7(6.1 \%)$ & 2.22 \\
\hline 9 & opportunities for promotion & $16(14.0 \%)$ & $51(44.7 \%)$ & $28(24.6 \%)$ & $13(11.4 \%)$ & $6(5.3 \%)$ & 2.18 \\
\hline 10 & opportunities for personal development & $18(15.8 \%)$ & $49(49.0 \%)$ & $27(23.7 \%)$ & $10(8.8 \%)$ & $10(8.8 \%)$ & 2.18 \\
\hline 11 & pay and other benefits attached to my job & $9(7.9 \%)$ & $40(35.1 \%)$ & $22(19.3 \%)$ & $27(23.7 \%)$ & $16(14.0 \%)$ & 1.98 \\
\hline \multirow[t]{2}{*}{12} & my work generally & $22(19.3 \%)$ & $54(47.4 \%)$ & $17(14.9 \%)$ & $16(14.0 \%)$ & $5(4.4 \%)$ & 2.52 \\
\hline & & & & & & Overall mean & 2.51 \\
\hline
\end{tabular}

Findings in Table 3 indicate an average score for organisational commitment among respondents as affirmed by the general mean score of 2.03 . While respondents may be said to be committed to their organisations, the table reveals that respondents have a higher level of psychological attachment to their libraries as affirmed by the mean sore of 2.61 for affective commitment than they have for the cost associated with leaving the organisation or the perceived obligation to remain with their organisations as shown in the mean score of 2.00 for continuance commitment and 1.49 mean score for normative commitment.

From the findings of the study it was obvious that respondents faced challenges related to job satisfaction and organisational commitment. Table 4 shows constraints to job satisfaction.

From Table 4 it was obvious that constraints to job satisfaction are mainly in the areas of promotion and benefits. Although other areas of challenges were noted by the respondents, the least areas of challenge were found to be gender discrimination and un-conducive office space.

From Table 5, it was obvious that the major constraints to organisational commitment among the study respondents are denied access to entitlements and benefits and lack of support for professional development. Although other factors were found as constraints to organisational commitment, lack of job security and un-conducive work environment formed the least of those constraints. 
Table 3. Organisational commitment.

\begin{tabular}{|c|c|c|c|c|c|c|c|}
\hline $\mathbf{S} / \mathbf{N}$ & Affective commitment & Strongly agree & Agree & Undecided & Disagree & Strongly disagree & Mean \\
\hline 1 & This library means a great deal to me & $28(24.6 \%)$ & $66(57.9 \%)$ & $17(14.9 \%)$ & $3(2.6 \%)$ & 0 & 2.77 \\
\hline 2 & $\begin{array}{l}\text { I believe that a person must be loyal } \\
\text { to his/her library }\end{array}$ & $42(36.8 \%)$ & $49(43.0 \%)$ & $17(14.9 \%)$ & $3(2.6 \%)$ & $3(2.6 \%)$ & 2.69 \\
\hline 3 & $\begin{array}{l}\text { I have a strong sense of belonging in } \\
\text { this library }\end{array}$ & $20(17.5 \%)$ & $68(59.6 \%)$ & $19(16.7 \%)$ & $6(5.3 \%)$ & $1(0.9 \%)$ & 2.61 \\
\hline 4 & $\begin{array}{l}\text { Things were better in the days when } \\
\text { people stayed with one library for } \\
\text { most part of their career }\end{array}$ & $7(6.1 \%)$ & $26(22.8 \%)$ & $42(36.8 \%)$ & $23(20.2 \%)$ & $16(14.0 \%)$ & 2.54 \\
\hline 5 & I am emotionally attached to this library & 19(16.7\%) & $64(56.1 \%)$ & $24(21.1 \%)$ & $6(5.3 \%)$ & $1(0.9 \%)$ & 2.46 \\
\hline \multicolumn{7}{|c|}{ Overall mean for affective commitment } & 2.61 \\
\hline \multicolumn{8}{|c|}{ Continuance commitment } \\
\hline 6 & $\begin{array}{l}\text { I may not likely get employed elsewhere } \\
\text { if I leave this library }\end{array}$ & $11(9.6 \%)$ & $37(32.5 \%)$ & $29(25.4 \%)$ & $25(21.9 \%)$ & $12(10.5 \%)$ & 2.31 \\
\hline 7 & $\begin{array}{l}\text { My life would be disrupted if I stop } \\
\text { working in this library }\end{array}$ & $10(8.8 \%)$ & $19(16.6 \%)$ & $26(22.8 \%)$ & $31(27.2 \%)$ & $28(24.6 \%)$ & 2.09 \\
\hline 8 & $\begin{array}{l}\text { Leaving this place would require } \\
\text { considerable personal sacrifice }\end{array}$ & 14(12.3\%) & $35(30.7 \%)$ & $34(29.8 \%)$ & 22(19.3\%) & $9(7.9 \%)$ & 1.90 \\
\hline 9 & $\begin{array}{l}\text { I have too few options to consider } \\
\text { leaving this library }\end{array}$ & $13(12.3 \%)$ & $37(32.5 \%)$ & $35(30.7 \%)$ & $17(14.9 \%)$ & $12(10.5 \%)$ & 1.88 \\
\hline 10 & $\begin{array}{l}\text { Right now, staying with this library is a } \\
\text { matter of necessity as well as desire }\end{array}$ & $13(11.4 \%)$ & 45(39.5\%) & $24(21.1 \%)$ & $9(16.7 \%)$ & $3(11.4 \%)$ & 1.83 \\
\hline \multicolumn{7}{|c|}{ Overall mean for continuance commitment } & 2.00 \\
\hline \multicolumn{8}{|c|}{ Normative commitment } \\
\hline 11 & $\begin{array}{l}\text { It would be hard for me to stop working } \\
\text { for this library, even if I want to }\end{array}$ & $12(10.5 \%)$ & 18(15.8\%) & $33(28.9 \%)$ & $30(26.3 \%)$ & $21(18.4 \%)$ & 1.64 \\
\hline 12 & $\begin{array}{l}\text { I am afraid of what might happen to me if } \\
\text { I quit my job without having another one }\end{array}$ & $28(24.6 \%)$ & $31(27.2 \%)$ & 25(21.9\%) & 19(16.7\%) & $11(9.6 \%)$ & 1.61 \\
\hline 13 & $\begin{array}{l}\text { If I get an offer of a better job, I would } \\
\text { not feel that is wrong to leave this place }\end{array}$ & 38(33.3\%) & $48(42.1 \%)$ & $21(18.4 \%)$ & 4(3.5\%) & $3(2.6 \%)$ & 1.47 \\
\hline 14 & $\begin{array}{l}\text { I was taught to believe in the value } \\
\text { of remaining loyal to one library }\end{array}$ & $16(14.0 \%)$ & 49(43.0\%) & $27(23.7 \%)$ & 13(11.4\%) & $9(7.9 \%)$ & 1.37 \\
\hline 15 & $\begin{array}{l}\text { I would be happy to spend the rest of } \\
\text { my career in this library }\end{array}$ & $6(5.3 \%)$ & 15(13.2\%) & $36(31.6 \%)$ & $30(26.3 \%)$ & 27(23.7\%) & 1.37 \\
\hline \multicolumn{7}{|c|}{ Overall mean for normative commitment } & 1.49 \\
\hline \multicolumn{7}{|c|}{ General mean score for organisational commitment } & 2.03 \\
\hline
\end{tabular}

Table 4. Constraints to job satisfaction.

\begin{tabular}{|c|c|c|c|}
\hline $\mathbf{S} / \mathbf{N}$ & Statement & Frequency & Percentage \\
\hline 1 & Stringent conditions for promotion & 60 & 52.6 \\
\hline 2 & Denied access to benefits & 51 & 44.7 \\
\hline 3 & Lack of job security & 49 & 43.0 \\
\hline 4 & Negative perception of librarians & 45 & 39.5 \\
\hline 5 & Lack of opportunity to exercise responsibility & 45 & 39.5 \\
\hline 6 & Un-conducive office space & 35 & 30.7 \\
\hline 7 & Gender discrimination & 26 & 22.8 \\
\hline
\end{tabular}


Table 5. Constraints to organisational commitment.

\begin{tabular}{clcc}
\hline S/N & \multicolumn{1}{c}{ Statement } & Frequency & Percentage \\
\hline 1 & Denied access to entitlements and benefits & 53 & 46.5 \\
2 & Lack of support for professional development & 49 & 43.0 \\
3 & Management policies are not clearly understood & 38 & 33.3 \\
4 & Inability to cope with organisational policies & 34 & 29.8 \\
5 & Lack of job security & 32 & 28.1 \\
6 & Un-conducive work environment & 28 & 24.6 \\
\hline
\end{tabular}

\subsection{Discussion of Findings}

Based on the findings of the study, it is evident that library personnel in private university libraries in Ogun State are generally satisfied with their jobs. This is in agreement with the findings of Sierpe [13]; Togia et al. [14] who found librarians at Quebec and Greece to be generally satisfied with their jobs. The findings, however, specifically revealed that library personnel in private university libraries in Ogun State, Nigeria have higher levels of job satisfaction with their relationship with supervisors, the physical library environment and cooperation received from co-workers. This is in agreement with the assertion of Mowday and Sutton [8] that job satisfaction is related to employees' opportunities for interaction with others in the job and the findings of Fanimehin and Popoola [17] which revealed that library personnel in the Federal Civil Service of Nigeria are mostly satisfied with the way co-workers relate with each other. It partially supports the findings of Bonnie [15] whose study of academic librarians in United States revealed that the greatest source of satisfaction of librarians were relationship with patrons, co-workers, assigned duties and variety of work.

Although many factors were found as constraints to job satisfaction, stringent conditions for promotion, denied access to benefits and lack of job security topped the list. This was also in agreement with the findings of Bonnie [15] whose study revealed that dissatisfaction came up as a result of opportunities for promotion, recognition of accomplishment and salary. The implication of these findings is that library personnel in private universities in Nigeria are yet to experience maximum job satisfaction. When compared in line with Maslows' hierarchy of needs [7], it is obvious that library personnel in private universities in Ogun State are within the belongingness and esteem level and are yet to get to the level of self-actualisation, which can be derived, through promotion and status.

Library personnel in private universities in Ogun State were also found to be generally committed to their organisations even though organisational commitment among the respondents was found to be lower than job satisfaction with the mean scores of 2.03 and 2.51 respectively which corroborates the findings of Hart [21]. While respondents may be said to be generally committed to their organisations, affective commitment was found to be higher that continuance or normative commitment. This implies that though respondents are affectionate about their libraries, they may, however, leave for what they might consider a better offer elsewhere.

Although, library personnel in private universities in Ogun State were found to be generally committed to their organisation, major constraints to organisational commitment were found to be denied access to entitlements and benefits and lack of support for professional development. This agrees with Harts' study [21], which revealed causes of low commitment to include a sense of stagnation, frustration with inadequate resources and anger at poor remuneration as the reasons for denied entitlements and lack of support for professional development can be tied to inadequate resources within the organisation.

\section{Conclusion and Recommendations}

Based on the findings, the study concludes that library personnel in private universities in Ogun State are satisfied with their jobs and are committed to their organisations even though they face certain constraints. Based on the findings, the study recommends that:

1) Library administrators should ensure that library personnel do not deny their entitlements.

2) Professional development for all cadres of library staff should be taken seriously in order to enhance job satisfaction and organisational commitment. 
3) Organisational policies should be properly communicated for easy assimilation among library personnel.

4) Library administrators should find ways of improving continuous and normative commitment among personnel to ensure that people not only want to work for the libraries but that they would also be unwilling to leave it even when faced with alternatives.

5) Although library personnel in the studied universities were found to be generally satisfied with their jobs, it was also obvious that their level of satisfaction can be improved to help them achieve self-actualisation, through training, recognition and promotion.

\section{References}

[1] Onuoha, U.D. (2008) Perception of Performance Appraisal as a Tool for Enhanced Productivity and Career Advancement in Three University Libraries in Ogun State, Nigeria. Babcock Journal of Management and Social Sciences, 6, 171-180.

[2] Cohen, A. (2003) Multiple Commitments in the Workplace: An Integrative Approach. Lawrence Erlbaum Associates Publishers, London.

[3] Steinhaus, C.S., James, L. and Perry, J.L. (1996) Organisational Commitment: Does Sector Matter? Public Productivity \& Management Review, 19, 278-288. http://dx.doi.org/10.2307/3380575

[4] Robbins, S.P. (1998) Organisational Behavior-Concepts, Controversies, and Applications. 8th Edition, Prentice Hall, Upper Saddle River.

[5] Glisson, C. and Durick, M. (1988) Predictors of Job Satisfaction and Organisational Commitment in Human Service Organizations. Administrative Science Quarterly, 33, 61-68. http://dx.doi.org/10.2307/2392855

[6] Robbins, S.P. and Judge, T.A. (2013) Organisational Behavior. 15th edition, Pearson, Boston.

[7] Maslow, A. (1943) A Theory of Human Motivation. Psychological Review, 50, 370-396. http://dx.doi.org/10.1037/h0054346

[8] Mowday, R. and Sutton, R. (1993) Organisational Behaviour: Linking Individuals and Groups to Organisational Contexts. Annual Review of Psychology, 44, 195-229. http://dx.doi.org/10.1146/annurev.ps.44.020193.001211

[9] Ting, Y. (1997) Determinants of Job Satisfaction of Federal Government Employees. Public Personnel Management, 26, 313-334.

[10] Moorhead, G. and Griffen, R.W. (1992) Organizational Behavior: Managing People and Organizations. 3rd Edition, Houghton Mifflin, Boston.

[11] Taylor, G.S. and Vest, M.J. (1992) Pay Comparisons and Pay Satisfaction among Public Sector Employees. Public Personnel Management, 21, 445-454.

[12] Luthans, F. (1998) Organisational Behaviour. 8th Edition, Irwin McGraw-Hill, Boston.

[13] Sierpe, E. (1999) Job Satisfaction among Librarians in English-Language Universities in Quebec. Library \& Information Science Research, 21, 479-499. http://dx.doi.org/10.1016/S0740-8188(99)00025-0

[14] Togia, A., Koustelios, A. and Tsigilis, N. (2004) Job Satisfaction among Greek Academic Librarians. Library \& Information Science Research, 26, 373-383. http://dx.doi.org/10.1016/j.lisr.2004.01.004

[15] Ingersoll, G.L., Olsan, T., Drew-Cates, J., DeVinney, B.C., Davies, J. and Bonnie, C.D. (2002) Nurses’ Job Satisfaction, Organisational Commitment and Career Intent. Journal of Nursing Administration, 32, 250-263. http://dx.doi.org/10.1097/00005110-200205000-00005

[16] Haque, M., Karim, A.N.M., Muqtadir, A. and Anam, S. (2012) Dimensions of Job Satisfaction of Library Professionals: A Qualitative Exploration. International Journal of Business and Social Research (IJBSR), 2, 46-62.

[17] Fanimehin, A.O. and Popoola, S.O. (2013) Effects of Career Progression, Work Motivation and Leadership Styles on Job Satisfaction of Library Personnel in the Federal Civil Service of Nigeria. International Journal of Library and Information Science, 5, 147-159.

[18] Zangaro, G.A. (2001) Organisational Commitment: A Concept Analysis. Nursing Forum, 36, 14-23. http://dx.doi.org/10.1097/00005110-200205000-00005

[19] Meyer, J.P. and Allen, N.J. (1997) Commitment in the Workplace: Theory, Research and Application. Sage, Thousand Oaks.

[20] Okpara, J.O. (2004) Job Satisfaction and Organisational Commitment: Are There Differences between American and Nigerian Managers Employed in the US MNCs in Nigeria? The Academy of Business and Administrative Sciences (ABAS) International Conference, Montreux, 12-14 June 2004.

[21] Hart, G. (2010) Job Satisfaction in a South African Academic Library in Transition. Journal of Academic Librarian- 
ship, 36, 53-62. http://dx.doi.org/10.1016/j.acalib.2009.11.006

[22] Curry, J.P., Wakefield, D.S., Price, J.L. and Mueller, C.W. (1996) On the Casual Ordering of Job Satisfaction, Job Involvement and Organisational Commitment. Academy of Management Journal, 27, 210-230.

[23] Baron, R.A. and Greenberg, J. (1990) Behaviour in Organizations. 3rd Edition, Ally and Bacon, London.

[24] Benkhoff, B. (1997) Ignoring Commitment Is Costly: New Approaches to Establish the Missing Link between Commitment and Performance. Human Relations, 26, 701-726. http://dx.doi.org/10.1177/001872679705000604 